\title{
APLIKASI CUTI DOSEN BERBASIS ANDROID PADA STEBIS ISLAM DARUSSALAM
}

\author{
Imam Solikin ${ }^{* 1}$, M. Soekarno Putra ${ }^{2}$ \\ 1,2 Universitas Bina Darma \\ Jln. Jendral A. Yani No. 03, Kota Palembang, Indonesia \\ 1Program Studi Manajemen Informastikan, 2Program Studi Teknik Informatika \\ 1imamsolikin@binadarma.ac.id, 22soekarno@binadarma.ac.id
}

\begin{abstract}
The development of information technology is currently growing which makes it easier for users with a mobile or android based system that can be used wherever and whenever the user wants. Bina Darma University Palembang is one of the private universities in Palembang that has been accredited B and has ISO standards. Bina Darma University has employees including employees and staff and lecturers. At Bina Darma University Palembang the process of filing leave is still done manually. Employees and lecturers who will propose leave are required to make and provide a leave of reference letter. By using this androidbased leave application, it makes it easier for lecturers or employees to carry out the process of filing leave, because it can be accessed anywhere and anytime so that it can improve the time in filing leave.
\end{abstract}

Keywords: Android, Leave, Lecturer

\section{Abstrak}

Perkembangan teknologi informasi saat ini yang semakin berkembang yang semakin memudahkan pengguna dengan adanya sistem berbasi mobile atau android yang dapat digunakan dimanapun dan kapanpun pengguna inginkan. Universitas Bina Darma Palembang merupakan salah satu Universitas swasta di kota Palembang yang telah terakreditasi B dan berstandar ISO. Universitas Bina Darma memiliki pegawai yang meliputi karyawan beserta staf dan dosen pengajar. Pada Universitas Bina Darma Palembang proses pengajuan cuti masih dilakukan secara manual. Karyawan dan dosen yang akan mengajukan cuti yaitu harus membuat dan memberikan surat pengacuan cuti. Dengan menggunakan aplikasi pengajuan cuti berbasis android ini memudahkan dosen ataupun karyawan dalam melakukan proses pengajuan cuti, karena dapat diakses dimanapun dan kapanpun sehingga hal ini dapat mengefienkan waktu dalam pengajuan cuti.

Kata kunci: Android, Cuti, Dosen

\section{PENDAHULUAN}

Teknologi informasi sekarang ini mengalami kemajuan sangat pesat, antara lain teknologi informasi berbasis android. Android merupakan sistem operasi untuk smarthpone yang menyediakan platform terbuka bagi para developers dalam menciptakan aplikasi mereka dengan bermacam-macam versi android yang sesui dengan kebutuhan pengguna android [1]. Smarthpone merupakan telephone 
selulur dengan mikroprosesor, memory, screen dan modem bawaan [2]. Adroid merupakan salah satu jenis kemajuan teknologi informasi yang banyak dimanfaatkan oleh perusahaan atau institusi. Dalam institusi salah satunya digunakan untuk sistem informasi dosen antara lain pengajuan cuti dosen, dimana dosen mengajukan cuti kerja dalam waktu tertentu.

Berdasarkan Kementerian Pendidikan dan Kebudayaan Republik Indonesia landasan hukum yang mengatur tentang cuti adalah Pasal 5 UU nomor 8 tahun 1974, Peraturan Pemerintah nomor 24 Tahun 1976 tentang Cuti Pegawai Negeri Sipil [3]. Menurut Undang-Undang No.13 tahun 2003 Pasal 79 ayat (2) [4]. Seorang pekerja berhak atas cuti tahunan sekurang kurangnya 12 hari kerja. Cuti itu sendiri terdiri dari cuti tahunan, cuti sakit, cuti melahirkan, cuti karena alasan tertentu.

STEBIS Islam Darussalam merupakan Sekolah Tinggi Ilmu Ekonomi dan Bisnis yang berada di Desa Tugu Mulyo Kecamatan Lempuing Kabupaten Ogan Komering Ilir. Pada STEBIS Islam Darussalam dalam proses pengajuan cuti dosen masih dilakukan menggunakan surat pengajuan kertas yang harus kemudian diserahakan kepada ketua jurusan untuk ditanda tangani atau persetujuan, setelah disetujuan kemudian diserahkan ke bagian Sumber Daya Manusia (SDM). Pada bagian SDM akan melakukan pengecekan sisa cuti yang dimiliki dosen yang bersangkutan dan menyetujuinya. Kemudian SDM melakukan penginputan data cuti dosen, menyerakan pengajuan cuti bagian keuangan dan kemudian keuangan menyerakan surat cuti yang telah disetujui kepada dosen. Dalam proses pengajuan cuti dosen yang menjadi permasalahan adalah dosen yang ingin mengajukan cuti terkadang tidak bisa datang langsung untuk mendapatkan tanda tangan persetujuan ketua jurusan dan untuk menyerahkan surat pengajuan cuti ke SDM.

Maka untuk mengatasi masalah di STEBIS Islam Darussalam perlu adanya pengembangan sistem berbasis teknologi informasi untuk mempermudah pengajuan cuti dosen antara teknolgi informasi berbasis android. Kemudahan dari teknologi informasi berbasis android ini antara lain dari segi pengajuan cuti yang dapat dilakukan dengan mengakses android dengan bantuan internet dan tidak perlu datang langsung ke STEBIS Islam Darussalam. Adapun tema pengembangan teknologi informasi dalam penelitian ini yaitu "aplikasi cuti dosen berbasis androi".

Penelitian ini mempunyai tujuan yaitu: 1) membangun aplikasi cuti yang dapat mendukung pemrosesan cuti yaitu cuti tahunan, cuti sakit, cuti melahirkan, cuti karena alasan tertentu, 2) membantu dosen untuk memonitor cuti dosen agar mendapatkan hak cutinya tepat waktu, 3) membantu pihak SDM dalam mendapatkan informasi data cuti dosen secara update dan memberikan informasi cuti kepada dosen, 4) memberikan informasi kepada dosen tentang data cuti yang telah maupun belum diambil. Adapun mafaat dari penelitian ini yaitu: 1) mempermudah dosen STEBIS Islam Darussalam dalam mengajukan cuti, 2) Mempermudah SDM dalam melakukan pendataan dan berbagi informasi data cuti dosen, 3) mempermudah instansi dalam memproses pengajuan cuti dosen.

Peneliti menggunakan penelitian-penelitian sebelumnya sebagai sumber referensi pendukung antara lain, "pembuatan sistem informasi cuti pada kantor pelayanan perbendaharaan negara dengan menggunakan php dan MySQL" [5], keterkaitan dengan penelitian ini sama-sam tenatang pengajuan cuti tetapi beda 
ojek penelitian dan sistem jalur pengajuannya. Kemudian, "aplikasi klasifikasi penentuan pengajuan kartu kredit menggunakan metode naive bayes di Bank BNI Syariah Surabaya" [6], kaitannya dengan penelitian ini sama proses sistem pengajuan (pengajuan kredit dan pengajuan cuti dosen). "Perancangan Sistem Informasi Pengolahan Data Absensi dan Pengambilan Surat Cuti Kerja Berbasis Web" [7], kaitanya dengan penelitian ini sama membahan pengajuan cuti tetapi cara atau basis yang digunakan berbeda (berbasis web mobile dan berbasis android).

"Sistem Informasi Pengajuan Cuti Pegawai Dinas Perhubungan Komunikasi dan Informatika Propinsi Sumatera Barat" [8], "Pengembangan Aplikasi Web untuk Pengajuan Cuti Pegawai Secara Online" [9], dan "Aplikasi Pengajuan Cuti Pada Human Resource Management Menggunakan PHP dan MYSQL (Studi Kasus Pada PT. INTILOKA)" [10]. Kaitan tiga penelitian tersebut dengan peneliti yang dilakukan adalah sama sistem yang digunakan untuk mengajuan cuti secara online akan tetapi penelitian tersebut lebih berbasis web dan penelitian yang dibangun berbasis android.

\section{METODOLOGI PENELITIAN}

\subsection{Metode Prototype}

Metode pengambangan aplikasi yang digunakan yaitu metode prototype. "Metode prototype digunakan untuk mendapatkan gambaran aplikasi yang akan dibangun melalui tahapan pembangunan aplikasi prototype terlebih dahulu dan akan dievaluasi oleh user" [13]. Tahapan metode prototype bisa dilihat pada gambar 1.

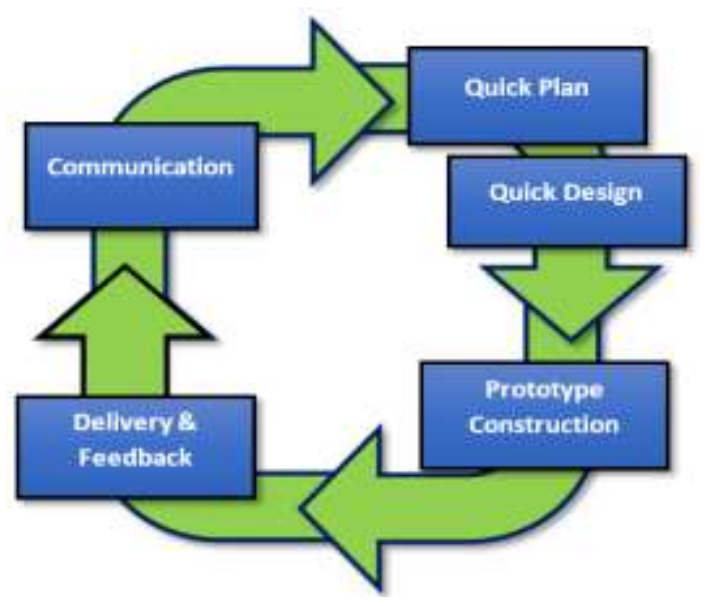

Gambar 1. Tahapan metode Prototyping [14]

a. Communication

Pada tahap communication dilakukan pengumpulan data yang sesuai dengan kebutuhan penelitian. Adapun proses pengumpulan data dikerjakan dengan tiga teknik pengumpulan data antara lain dengan wawancara bebas terpimpin [11], observasi [12], dan dokumentasi [12]. Pada teknik wawancara dilakukan dengan bertanya kepada dosen yang terdiri dari 3 dosen, ketua jurusan, dan 
bagian sumber daya manusia (SDM) STEBIS Islam Darussalam. Adapun pertanyaan tersebut berkaitan dengan proses alur pengajuan cuti dosen STEBIS Islam Darussalam. Pada teknik observasi dilakukan dengan mencatat proses alur pengajuan cuti. Pada teknik dokumentasi dilakukan dengan cara memperoleh data dan informasi dalam bentuk arsip surat pengajuan cuti dan dokumen alur pengajuan cuti.

Pada proses pengajuan surat cuti yang dilakukan dosen adalah dosen membuat surat pengajuan cuti, kemudian mengajukan ke ketua jurusan untuk memintak persetujuan dan tanda tangan, kemudian menyerahkan ke SDM untuk ditinda lanjuti. Dalam proses pengajuan surat cuti dosen yang kadang menjadi permasalahan adalah dosen yang ingin mengajukan surat cuti tidak bisa datang langsung untuk memintak persetujuan dan menyerahkan surat pengajuan cuti secara langsung.

Solusi untuk mengatasi permasalah pengajuan surat cuti di STEBIS Islam Darussalam dengan membangun aplikasi pengajuan cuti berbasis adroid. Keuntungan pengunaan aplikasi berbasis android adalah mempermudah dosen dalam melakukan proses pengajuan surat cuti, karena dapat diakses dimanapun dan kapanpun sehingga tidka perlu datang langsung hal ini dapat mengefisienkan waktu dalam pengajuan cuti.

b. Quick plan

Pada tahap ini peneliti membuat permodelan sementara untuk aplikasi baru yang dapat membantu sistem yang sedang berjalan saat ini dan pembuatan program untuk aplikasi cuti dosen pada STEBIS Islam Darussalam.

c. Quick design

Pada tahap quick design berbasis android yang terdiri dari use case diagram, dan activity diagram. "Use case diagram merupakan rangkaian tindakan yang dilakukan oleh sistem, aktor mewakili user atau sistem lain yang terinteraksi dengan sistem yang dimodelkan" [15]. " Activity diagram digunakan untuk menggambarkan struktur sistem dari segi pendefinisian kelas-kelas yang akan dibuat untuk membangun sistem" [16]

d. Construction of Prototype

Pada tahap ini peneliti melakukan pembuatan protopype aplikasi Cuti dosen pada STEBIS Darussalam yang merupakan terjemahan dari tahapan desain aplikasi.

e. Deployment, Delivery \& Feedback

Tahap ini digunakan untuk evaluai yang dilakukan oleh pengguna, yang berupa feeback yang digunakan untuk meningkatkan kebutuhan aplikasi.

\section{HASIL DAN PEMBAHASAN.}

\subsection{Use Case Diagram}

Aplikasi cuti dosen salah satunya dibangun menggunakan use case diagram yang terdiri dari dosen, ketua jurusan, dan SDM. Gambar 2 yang merupkan perancangan aplikasi Cuti Dosen menggunakan use case. Aplikasi cuti tersebut dapat diakses melalui smartphone android, adapun user-nya yaitu Dosen, Ketua Jurusan, dan Kabag SDM (Sumber Daya Manusia). Dosen dapat mengajukan cuti, 
melihat hasil verifikasi cuti, melihat informasi cuti. Ketua Jurusan dapat melihat hasil pengajuan cuti dosen, melakukan verifikasi cuti yang diterukan ke Kabag SDM. Kabag SDM dapat melakukan verifikasi setelah ketua jurusan men-verifikasi terlebih dahulu yang menghasilkan notifikasi bagi diterima oleh dosen. Use case diagram aplikasi cuti dosen, digambarkan pada gambar 2 .

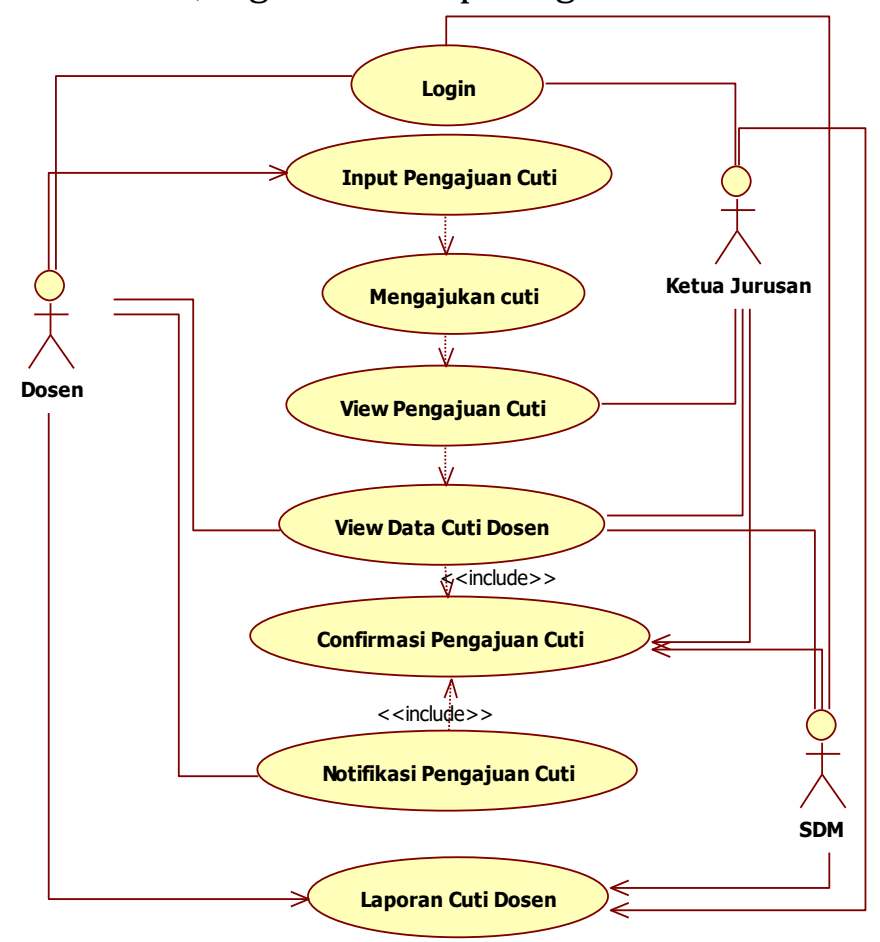

Gambar 2. Usecase diagram aplikasi cuti dosen berbassis android

\subsection{Activity Diagram}

Berikut ini rancangan Activity Diagram dari sistem yang dibuat yaitu sebagai berikut :

a. Activity diagram dosen dengan sistem

Dosen, untuk masuk ke aplikasi cuti dosen harus melakukan login terlebih dahulu dengan menggunakan username dan password kemudian di-verifikasi oleh sistem apakah hal akses yang digunakan sesuai atau tidak. Apabila dosen sudah berhasil login dosen bisa mengsisi form pengajuan cuti yang dikirim melalui aplikasi cuti dosen dengan beberpa proses yang kemudian mengahsilkan informasi cuti. Activity diagram dosen dengan sistem, digamabarkan pada gambar 3. 


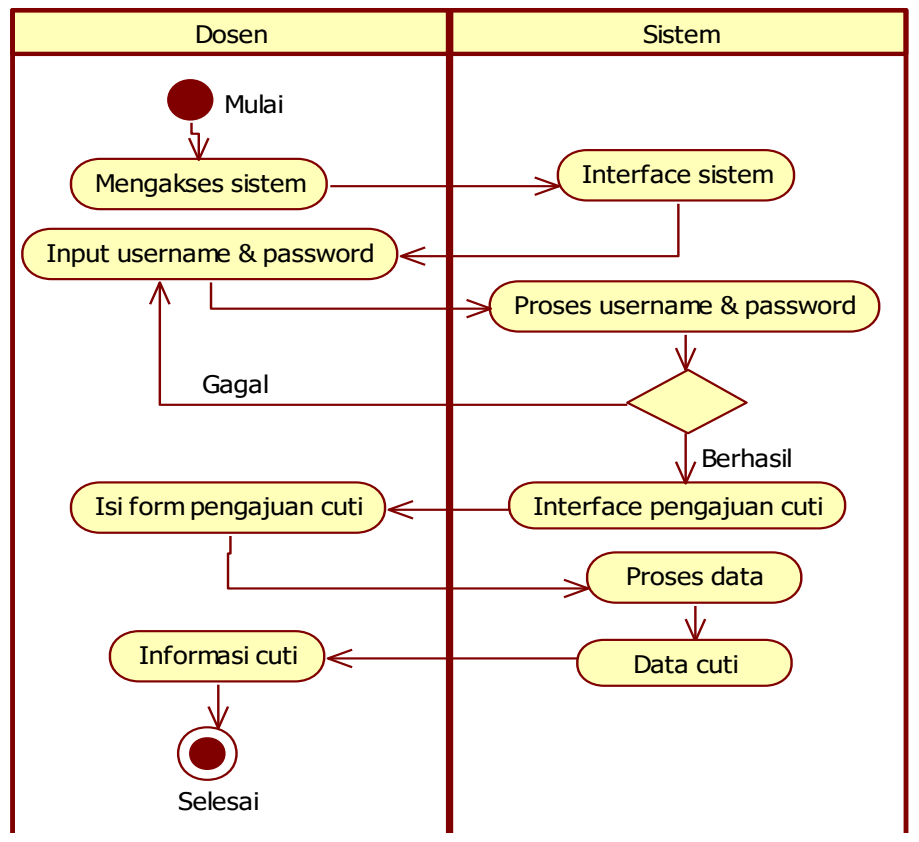

Gambar 3. Activity diagram dosen dengan sistem

b. Activity diagram ketua jurusan dengan sistem

Adapun activity diagram ketua jurusan dengan sistem, digambarkan pada gambar 4.

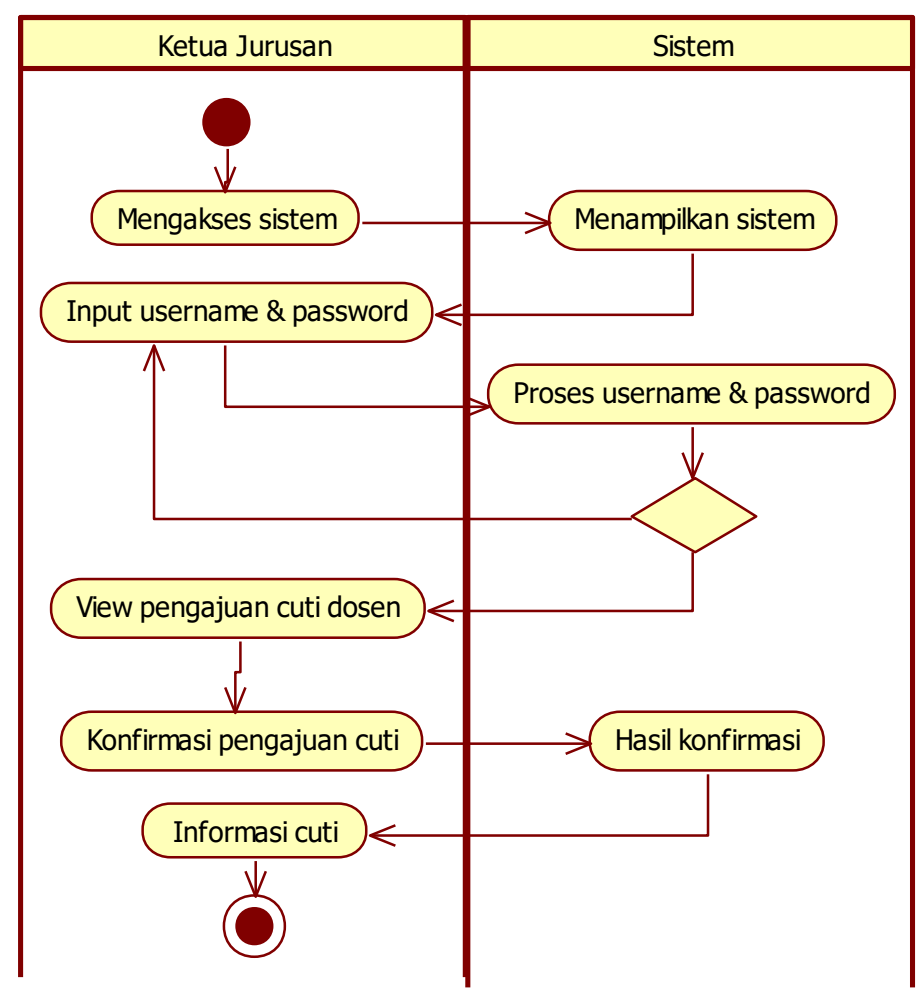

Gambar 4. Activity diagram ketua jurusan dan sistem 
Ketua jurusan, untuk masuk ke aplikasi cuti ketua jurusan harus melakukan login terlebih dahulu sesuai dengan hak akses yang dimiliki, apakah sesuai atau tidak untuk masuk ke aplikasi. Apabila ketua jurusan sudah berhasil login ketua jurusan bisa melakukan verifikasi pengajuan cuti dosen kemudian diteruskan ke Kabag SDM untuk verifikasi lanjutan Activity diagram Kepala Bagian Sumber Daya Manusia (SDM).

c. Activity diagram kapala bagian sumber daya manusia (SDM) dengan sistem Kabag SDM, untuk masuk ke aplikasi cuti ketua jurusan harus melakukan login terlebih dahulu menggunakan menggunakan hak akses yang dimiliki apakah username dan password yang dimasukan sesuai atau tidak. Apabila Kabag SDM sudah berhasil login Kabag SDM melakukan verifikasi lanjutan yang menghasilkan notifikasi untuk dosen yang melakukan pengajuan cuti. Activity diagram Kabag SDM dengan sistem, digambarkan pada gambar 5.

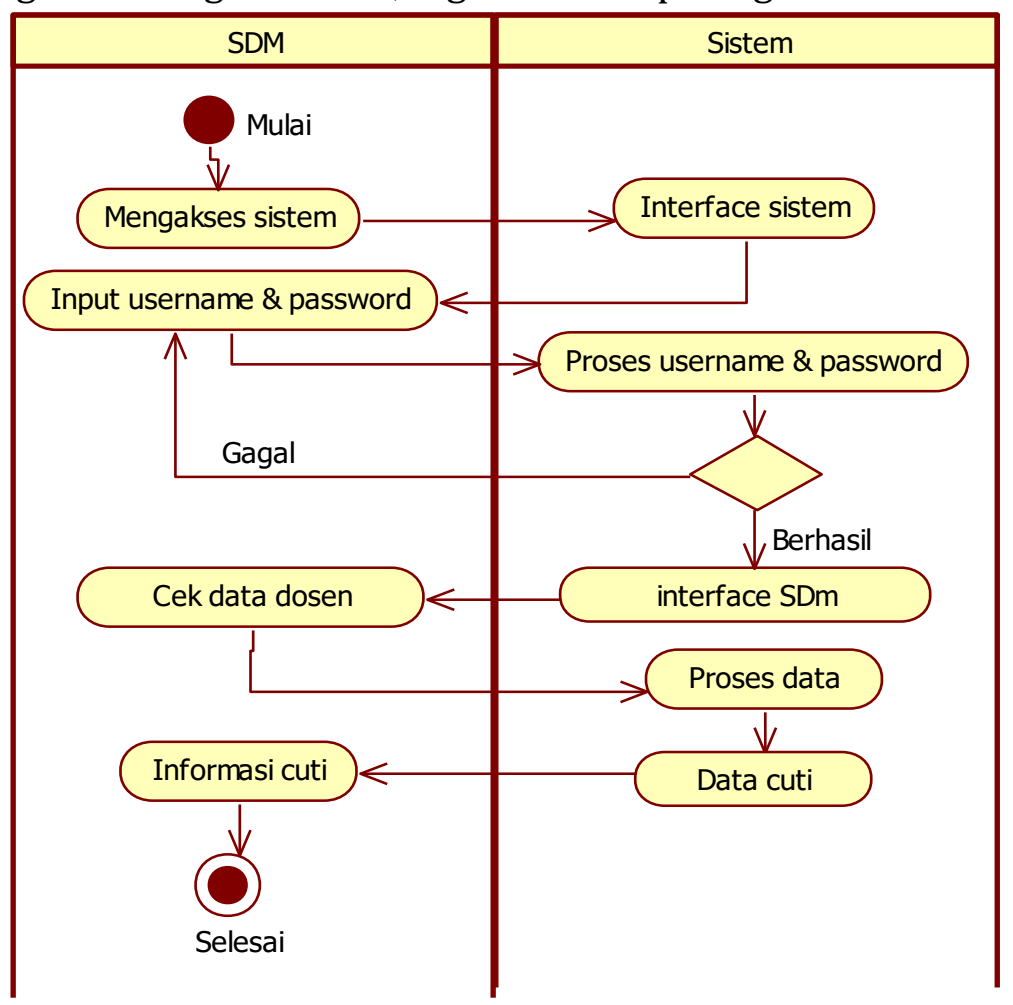

Gambar 5. Activity diagram Kabag SDM dan sistem

\subsection{Prototype Construction}

Pada tahan ini merupakan penerapan dari tahapan desain sistem menjadi bentuk prototype sistem, hasil dari tahap ini antara lain sebagai beriku:

a. INTERFACE login web, interface ini digunakan untuk ketua jurusan dan Kepala Bagian sumber daya manusia (SDM) untuk masuk ke aplikasi menggunakan hak akses yang dimiliki. Interface login web dapat dilihat pada gambar 6. 


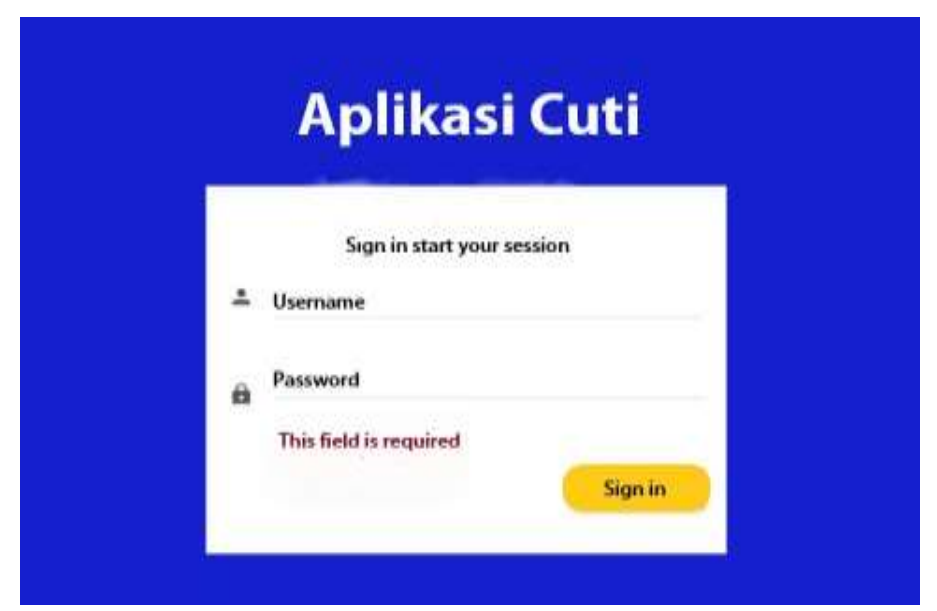

Gambar 6. Login web

b. Interface index Kabag SDM (sumber daya manusia)

Pada interface ini difungsikan sebagai penginputan data-data master antara lain data ketua jurusan, data dosen, data aktifitas cuti, sampai pengunaan untuk membuat laporan dan informasi cuti yang sampaikan pada ketua jurusan dan dosen. Index interface Kabag SDM dapat dilihat pada gambar 7, dan untuk interface laporan pada web SDM dapat dilihat pada gambar 8.

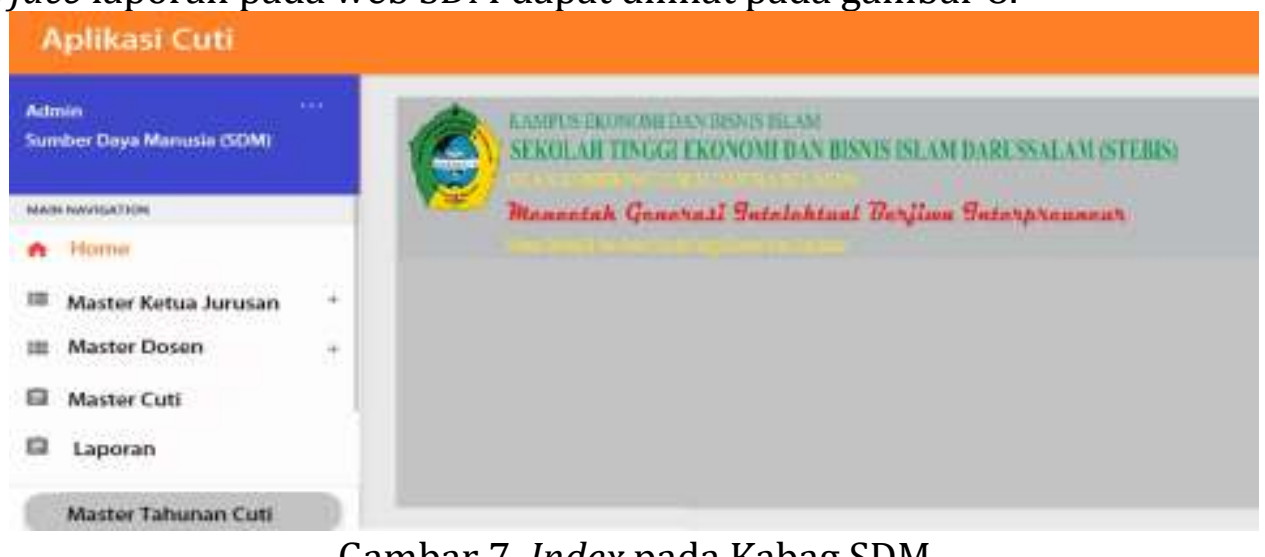

Gambar 7. Index pada Kabag SDM

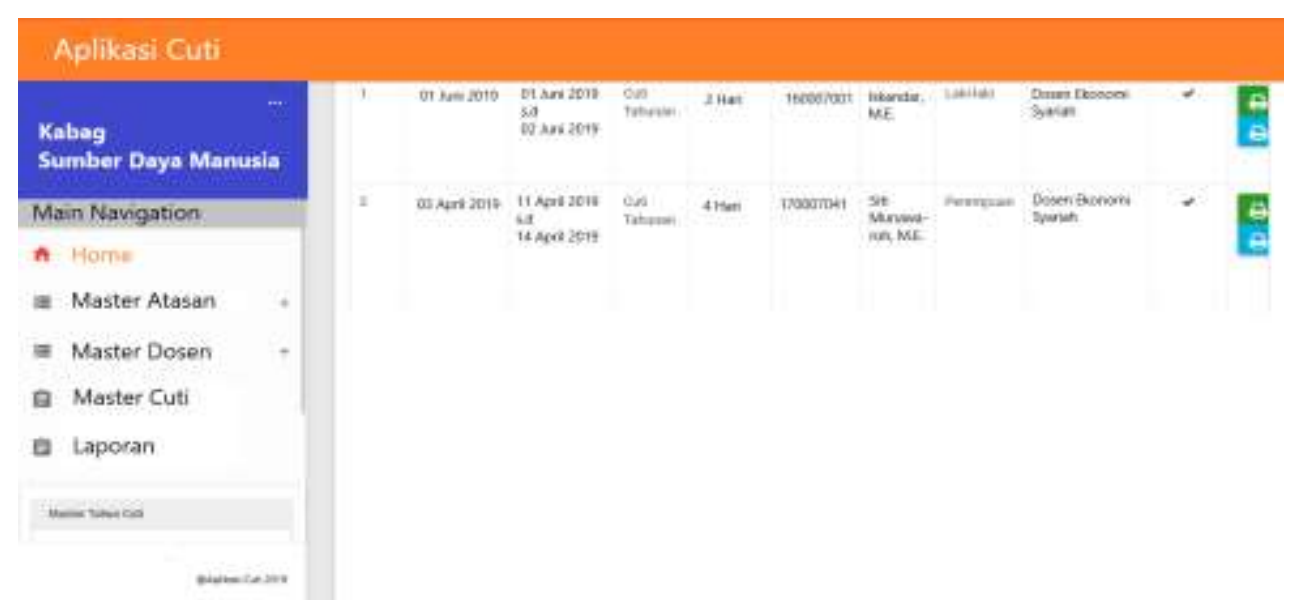

Gambar 8. Laporan pada Kabag SDM 
c. Interface login aplikasi Android

Interface login aplikasi android digunakan untuk masuk kesistem berbasis adroid. Aplikasi ini dapat diakses oleh SDM, Ketua jurusan dan Dosen. Untuk masuk kersistem menggunakan hak akses yang dimiliki yaitu username dan password. Interface login aplikasi android ditampilkan pada gambar 9.

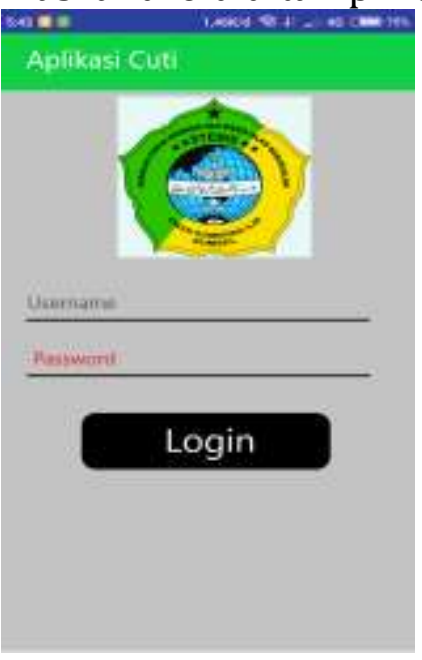

Gambar 8. Login aplikasi android

d. Aplikasi cuti dosen

Pada interface ini menampilkan fasilitas menu pengajuan cuti, dan informasi cuti. Pada menu pengajuan cuti mempermudah dosen untuk mengajukan cuti secara online dan tidak perlu datang langsung kekampus. Pada menu pengajuan ini juga mempermudah dosen apabila pengajuan cutinya dilakukan secara tibatiba. Dalam pengangajuan cuti harus mengisi form secara lengkap. Interface awal aplikasi cuti dosen dapat ditampilkan pada gambar 9, dan form pengajuan cuti ditampilkan pada gambar 10 .

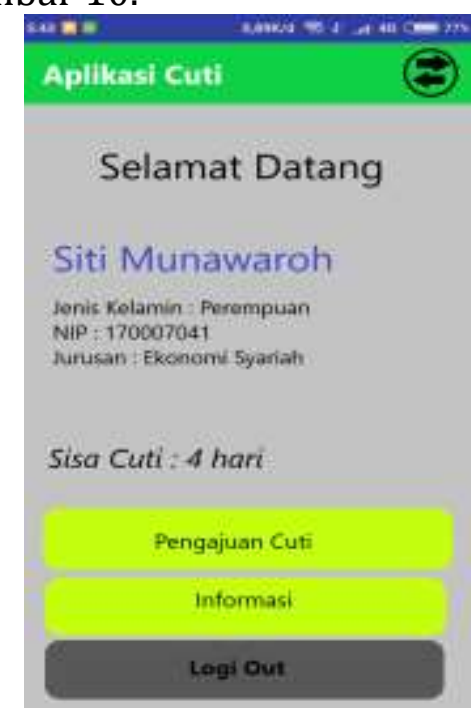

Gambar 9. Interface awal aplikasi cuti dosen 
e. Informasi

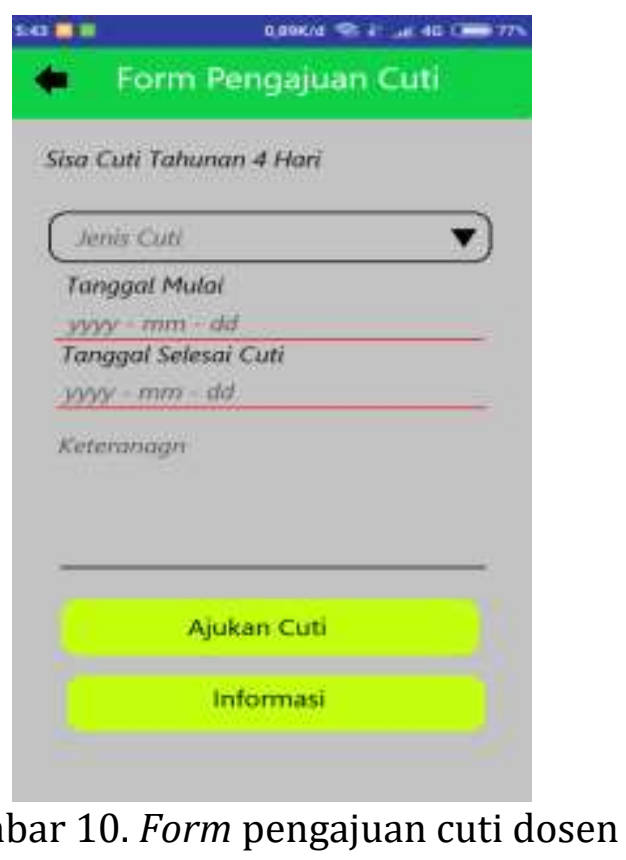

Pada interface informasi digunakan untuk mengetahui informasi status cuti apakah cuti yang diambil diterima atau tidak diterima, interface juga menampilakan data-data cuti yang berupa rincian cuti dan sisa cuti. Interface data informsi cuti dapat ditampilkan pada gambar 11.

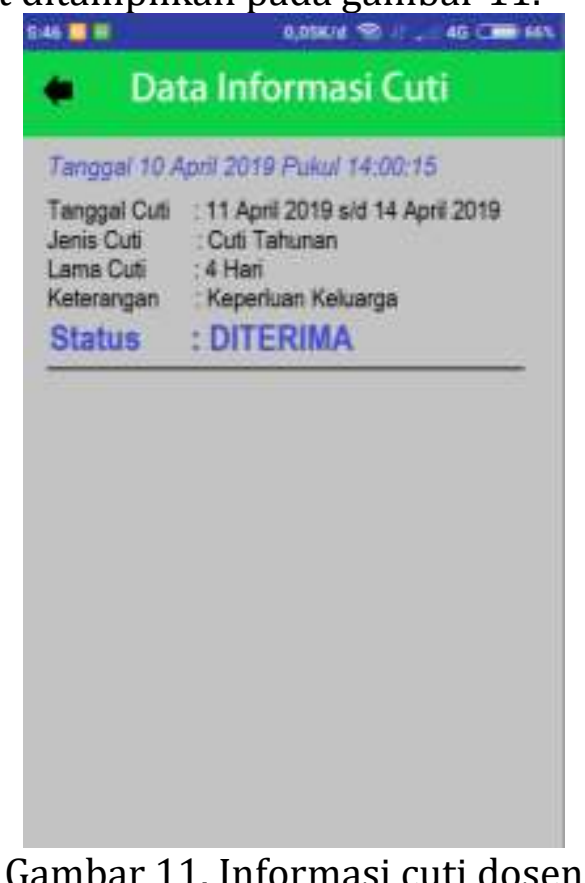

f. Validasi pengajuan cuti

Interface ini hanya dapat diakses oleh ketua jurusan dalam mevadasi pengajuan cuti, apakah cuti diterima atau di tolak, juga mempunyai fasilitas cetak surat pengjuan cuti. Interface validasi pengajuan cuti dapat dilihat pada gambar 12 . 


\section{SIMPULAN}

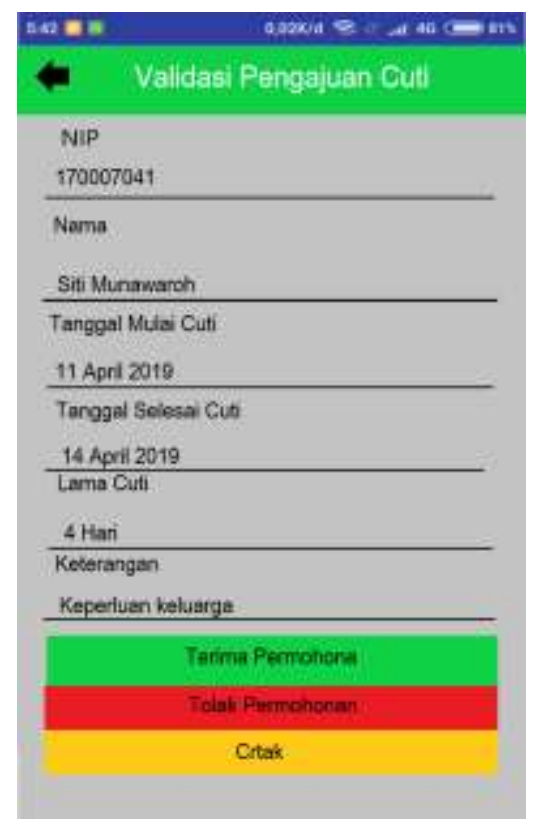

Gambar 12. Validasi pengajuan cuti dosen

Adapun kesimpulan yang didapat dalam penelitian ini anatara lain :

a. Dengan memanfaatkan kemajuan teknologi smartphone berbasis android ini dapat mendukung dan memberi kemudahan dalam proses cuti dan mendapatkan informasi tetang cuti dosen pada STEBIS Darussalam. Adapun cuti yang bisa diajukan berupa cuti tahunan atau cuti melahirkan.

b. Dengan adanya aplikasi cuti dosen pada STEBIS Darussalam ini, membantu SDM, ketuajurusan, dan dosen dalam memonitor waktu cuti agar mereka dapat mendapatkan hak cutinya tepat waktu.

\section{DAFTAR PUSTAKA}

[1] I. Solikin, "Implementasi Penggunaan Smartphone Android untuk Control PC (Personal Computer)," J. Inform. J. Pengemb. IT, vol. 3, no. 2, pp. 249-252, 2018.

[2] B. K. Williams and S. C. Sawyer, Using information technology: A practical introduction to computers \& communications. 2007.

[3] P. N. R. Indonesia, "Undang-Undang Nomor 5 Tahun 2014 tentang Aparatur Sipil Negara," 2014.

[4] Indonesia, Undang-Undang RI no. 13 tahun 2003 Tentang Ketenagakerjaan. Cipta Jaya, 2003.

[5] A. Setiyanto and F. Samopa, "Pembuatan Sistem Informasi Cuti pada Kantor Pelayanan Perbendaharaan Negara dengan Menggunakan PHP dan MySQL," J. Tek. ITS, vol. 2, no. 2, pp. A381-A384, 2013.

[6] M. Antaristi and Y. I. Kurniawan, "Aplikasi Klasifikasi Penentuan Pengajuan Kartu Kredit Menggunakan Metode Naive Bayes di Bank BNI Syariah Surabaya," J. Tek. Elektro, vol. 9, no. 2, pp. 45-52, 2017.

[7] A. L. Setyabudhi, "Perancangan Sistem Informasi Pengolahan Data Absensi 
dan Pengambilan Surat Cuti Kerja Berbasis Web," JR J. RESPONSIVE Tek. Inform., vol. 1, no. 1, 2017.

[8] K. Rohendi, "Sistem Informasi Pengajuan Cuti Pegawai Dinas Perhubungan Komunikasi dan Informatika Propinsi Sumatera Barat," J. TeknoIf, vol. 3, no. 2, 2015.

[9] G. A. Syaripudin and R. Cahyana, "Pengembangan Aplikasi Web untuk Pengajuan Cuti Pegawai Secara Online," J. Algoritm., vol. 12, no. 1, 2015.

[10] E. Orlando, "Aplikasi Pengajuan Cuti Pada Human Resource Management Menggunakan PHP dan MYSQL (Studi Kasus Pada PT. INTILOKA)," J. Ilm. KOMPUTASI, vol. 16, no. 3, pp. 275-284, 2017.

[11] S. Arikunto, "Prosedur Penelitian suatu Pendekatan Pra ktik." Jakarta, 2013.

[12] P. Sugiyono, "Metode penelitian kombinasi (mixed methods)," Bandung Alf., 2015.

[13] A. A. Pradipta, Y. A. Prasetyo, and N. Ambarsari, "Pengembangan Web ECommerce Bojana Sari Menggunakan Metode Prototype," eProceedings Eng., vol. 2, no. 1, 2015.

[14] R. S. Pressman, "Maxim BRSoftware engineering: A practitioner's approach.< ed> 8</ed> th ed." New York: McGraw-Hill Education, 2015.

[15] J. W. Satzinger, R. B. Jackson, and S. D. Burd, Systems analysis and design in a changing world. Cengage learning, 2011.

[16] R. A. Sukamto and M. Shalahuddin, "Rekayasa Perangkat Lunak," Bandung Inform., 2013.

[17] I. Indrajani, "Master data management model in company: challenges and opportunity," ComTech Comput. Math. Eng. Appl., vol. 6, no. 4, pp. 514-524, 2015. 